\section{Rice Hulls, Leaf-waste Pellets, and Pine Bark as Herbicide Carriers for Container-grown Woody Ornamentals}

\author{
Jayesh B. Samtani ${ }^{1}$, Gary J. Kling ${ }^{1,3}$, Hannah M. Mathers ${ }^{2}$, \\ and Luke Case ${ }^{2}$
}

AdDitional Index wORDs. Spiraea japonica, Thuja occidentalis, Spiraea nipponica, annual weeds, oryzalin, diuron

SUMMARY. An integrated approach to weed control in nursery containers is crucial if herbicide applications during the growing season are to be reduced. This experiment, conducted in 2002 and 2003 in Urbana, Ill., evaluated rice hulls, leaf-waste pellets, and pine bark as herbicide carriers for the preemergence herbicides oryzalin at $2 \mathrm{lb} /$ acre a.i. and diuron at $1 \mathrm{lb} /$ acre a.i. The efficacy of the treatments in controlling annual weeds and the phytotoxic effects of the treatments on the woody plant species were evaluated in separate completely randomized designs. For the efficacy experiment, no ornamental plants were present and containers were each seeded with a mixture of $1: 1: 1$ (by volume) of annual bluegrass (Poa annua), common groundsel (Senecio vulgaris), and shepherd's purse (Capsella bursa-pastoris) immediately after treatment applications. For the phytotoxicity experiment, 'Goldflame' spirea (Spivaea japonica), 'Hetz Midget' american arborvitae (Thuja occidentalis), and 'Snowmound' nippon spirea (Spiraea nipponica) were evaluated. No weed seeds were sown in the phytotoxicity containers. Treatments for both experiments included spray applications of herbicides with water or with one of the organic mulches as a carrier or one of the mulches alone. Evaluations were done 45 and 120 days after treatment (DAT) in both years. The organic carriers with herbicide sprays gave efficacy visual ratings equivalent to water as a carrier for both herbicides. Phytotoxicity was not observed in the spirea species in either year. For 'Hetz Midget' american arborvitae in 2002, diuron with water had the highest visual phytotoxicity rating. Diuron phytotoxicity on the 'Hetz Midget' american arborvitae was alleviated when diuron was applied with any of the three mulches as a carrier. Pine bark treatments increased plant biomass for 'Goldflame' spirea in 2003, 45 DAT. At 120 DAT in 2002, pine bark gave increased plant biomass as compared with no organic mulch treatments for 'Goldflame' spirea. The study was conducted to ascertain whether the use of organic mulches as carriers could reduce phytotoxic effects of a herbicide on container-grown woody ornamentals, improve crop plant biomass, and act as a herbicide carrier for container-grown woody ornamentals.

$\mathrm{W}$ eed management in container production is one of the major problems facing the nursery industry. Annual weeds in particular have the ability to grow under a wide range of environmental conditions. As a result of their small size and limited reserves, successful germination of annual weed species

\footnotetext{
${ }^{1}$ Department of Natural Resources and Environmental Sciences, University of Illinois, 1201 S. Dorner Drive, Urbana, IL 61801

${ }^{2}$ Department of Horticulture and Crop Sciences, The Ohio State University, 2001 Fyffe Court, Columbus, $\mathrm{OH} 43210$.

This paper is a portion of a master's thesis submitted by Jayesh B. Samtani at the University of Illinois.

We thank the Arboretum staff at the University of Illinois for their timely help in conduct of the experiment and David Seigler for weed identification. We also thank John Masiunas, Margaret Norton, and Vasey Mwaja for their suggestions on improving the manuscript.

${ }^{3}$ Corresponding author. E-mail: gkling@uiuc.edu.
}

occurs at the soil surface or at a shallow depth (Popay and Roberts, 1970). Annual bluegrass thrives best under cool, moist, and fertile conditions. In northern parts of the United States, it may be more of a summer annual than a winter annual. It is unable to tolerate extreme conditions and may die under such conditions (Holm et al., 1997). Common groundsel is a summer or winter dicotyledonous annual that reproduces by seed with optimal temperatures for germination ranging from 10 to $25{ }^{\circ} \mathrm{C}$ (Ren and Abbott, 1991). Extremely hot and dry conditions may lead to its death (Uva et al., 1997). Certain strains of common groundsel are found to be atrazineresistant and glyphosate-resistant and are of great concern to the nursery industry (Mathers, 2002). Shepherd's purse is mainly a problem weed in temperate areas, and in the tropics it is found only at higher elevations. In the case of nondormant weed species exposed to light, increased seed germination is observed when the temperature fluctuates from a low of 15 ${ }^{\circ} \mathrm{C}$ to an optimal high of 25 to $30{ }^{\circ} \mathrm{C}$ (Popay and Roberts, 1970). Controlling weeds in container plants becomes essential as a result of the limited availability of nutrients, water, and space to the landscape plant. Weed occurrence in containers can cause growth reduction of woody ornamentals by nearly $50 \%$ in a single growing season (Fretz, 1972) and decrease the aesthetic value of the crop plant.

Hand weeding is not an economic solution to weed control in nursery containers as a result of the high cost of labor. Because nursery growers can spend up to $\$ 4000 /$ acre on manual removal of weeds in containers depending on weed species (Mathers, 2003), chemicals are used to control weeds in a more costeffective manner. Issues pertaining to direct herbicide application in container-grown ornamental plants include the need for repeated herbicide application, nonuniform applications of herbicide, herbicide loss to the environment, and phytotoxicity.

\begin{tabular}{llll}
\hline $\begin{array}{l}\text { Units } \\
\text { To convert U.S. to SI, } \\
\text { multiply by }\end{array}$ & U.S. unit & SI unit & $\begin{array}{l}\text { To convert SI to U.S., } \\
\text { multiply by }\end{array}$ \\
\hline 0.4047 & $\mathrm{acre}(\mathrm{s})$ & $\mathrm{ha}$ & 2.4711 \\
0.3048 & $\mathrm{ft}$ & $\mathrm{m}$ & 3.2808 \\
9.3540 & $\mathrm{gal} / \mathrm{acre}$ & $\mathrm{L} \cdot \mathrm{ha}^{-1}$ & 0.1069 \\
2.5400 & inch $(\mathrm{es})$ & $\mathrm{cm}$ & 0.3937 \\
1.1209 & $\mathrm{lb} / \mathrm{acre}$ & $\mathrm{kg} \cdot \mathrm{ha}^{-1}$ & 0.8922 \\
0.5933 & $\mathrm{lb} / \mathrm{yard}^{3}$ & $\mathrm{~kg} \cdot \mathrm{m}^{-3}$ & 1.6856 \\
28.3495 & $\mathrm{oz}$ & $\mathrm{g}$ & 0.0353 \\
37.0798 & $\mathrm{oz} / \mathrm{yard}^{3}$ & $\mathrm{~g} \cdot \mathrm{m}^{-3}$ & 0.0270 \\
4.9289 & teaspoon & $\mathrm{cm}^{3}$ & 0.2029 \\
$\left({ }^{\circ} \mathrm{F}-32\right) \div 1.8$ & ${ }^{\circ} \mathrm{F}$ & ${ }^{\circ} \mathrm{C}$ & $\left(1.8 \times{ }^{\circ} \mathrm{C}\right)+32$
\end{tabular}


Direct spray application of herbicides to containerized plants can result in leaf scorch, chlorosis on leaves and stems, and reduced plant growth (Adams, 1990). As much as $80 \%$ of broadcast herbicide may settle into spaces between containers (Gilliam et al., 1992) and leach or move offsite with runoff water. In many cases, uniform application of herbicides to the soil of containerized plants may not be possible because plant canopies irregularly cover the containers (Gorski, 1993).

As a result of increasing financial and environmental concerns, recent research focus has been on minimizing chemical use yet ensuring profitability in nursery crop production (Mathers, 2003). An integrated approach to controlling weeds that incorporates more than one control measure, including chemicals, thus becomes important. Herbicide carriers could help reduce the problem of quick release of herbicides into the environment. Geotextiles, when used in combination with preemergence herbicides, gave superior weed control (Appleton and Derr, 1990). Slow-release herbicide tablets were effective in reducing herbicide phytotoxicity to crop plants (Koncal et al., 1981). Discs made of fabric and plastic materials were equally effective or better in controlling weeds in containers than hand-weeding, herbicides, or geotextile fabrics (Chong, 2003). Organic mulches can be used to control weeds, conserve moisture in the soil, regulate soil temperature, and decrease weed seed germination, thus improving plant growth and reducing labor. Although the primary use of mulches in the horticulture industry is in the landscape, they can serve as herbicide carriers in container production. Oryzalin-treated douglas fir bark increased weed control by a factor of 1.8 and the duration of efficacy by a factor of 2.8 compared with bark alone. Compared with the application of the herbicide in water, the herbicide-treated bark also reduced phytotoxicity by 2.2 times and increased efficacy by 1.5 times (Mathers, 2003).

This study evaluated and compared rice hulls, landscape leaf-waste pellets, and pine bark as carriers for the preemergence herbicides oryzalin and diuron. The dinitroaniline herbicide group, which includes oryzalin, is the most widely used group of herbicides in nursery and landscape settings for the control of grassy weeds and small-seeded broadleaf weeds. Diuron is registered as a preand postemergent herbicide for a number of agronomic and fruit crops and has a half-life of $90 \mathrm{~d}$ (Monaco et al., 2002). It belongs to the urea group of herbicides that disrupt the photosynthetic process of susceptible plants. When applied postemergent, urea herbicides act as contact burners affecting only the stems and foliage, whereas the plant roots remain unaffected. The affected plants show yellowing of the foliage with eventual defoliation, leaving only the stem (Monaco et al., 2002). Diuron is potentially phytotoxic to spirea and several other ornamental plants (Simpson et al., 2004) making a good test system for the ability of organic mulches to reduce phytotoxicity.

Pine bark is a common and popular material used for mulching and as a media component. When used as mulch, pine bark can inhibit weed seed germination while allowing water to percolate through (Aaron, 1972). Pine bark is mixed with components like peat, sand, vermiculite, and perlite to form container media and is frequently used in container media to replace peatmoss, a relatively costly product (Laiche, 1990; Pokorny, 1966). Rice hulls are byproducts of the rice milling process and can be obtained inexpensively in large quantities from major rice-producing states including Arkansas, California, Louisiana, Mississippi, and Texas (Einert and Baker, 1973; Hough and Barr, 1956; Laiche and Nash, 1990). Rice hulls can be used to substitute for sand in containerized bare root whip production (Struve and McCoy, 1996) by improving the drainage and aeration of the media and adding manganese (Einert and Baker, 1973). Deciduous landscape leaves are a major waste product in suburban landscape settings. There is a potential use for this waste product that could improve nursery production efficiency and reduce environmental pollution. The objective of this study was to evaluate and compare rice hulls, landscape leaf-waste pellets, and pine bark as herbicide carriers for preemergence herbicides in the control of annual weeds in container-grown ornamental plants.

\section{Materials and methods}

This study was conducted in 2002 and 2003 at the Landscape Horticulture Research Center in Urbana, Ill. (LHRC). The experiment consisted of two parts: 1) efficacy, for determining the effectiveness of the treatments in controlling annual weeds; and 2) phytotoxicity, for determining the effects of the herbicides on woody ornamentals. In 2002, rice hulls (commercial source unknown) and pine bark mulch (Harold Tatman and Sons, Adelphi, Ohio) were acquired through The Ohio State University. The leaf pellets were made from landscape leaf waste collected in the fall (Urbana, Ill.), dried in an oven, ground, and then pelletized (CPM Master Model; California Pellet Mill, Crawfordsville, Ind.). The leaves collected were from deciduous woody ornamentals, including american sycamore (Platanus occidentalis), sugar maple (Acer saccharum), silver maple (Acer saccharinum), red oak (Quercus rubra), pin oak (Quercus palustris), white ash (Fraxinus americana), and a small proportion of other minor species. Pellet dies of 12 inches in diameter and hole patterns of $0.2 \times$ 1.5 inches were used to pelletize the ground leaf mulch. The protocol followed for pelletizing the leaves was developed by the California Pellet Mill. Steam was used in the pelletizing process to improve pellet density and integrity.

For the efficacy experiment, no woody plants were present. Containers of 6.5 inches in diameter (nursery l-gal) were filled with a media of $70 \%$ pine bark, $20 \%$ sphagnum peat, $10 \%$ coarse sand, $2 \mathrm{oz} /$ yard $^{3}$ wetting agent, and $2 \mathrm{lb} /$ yard $^{3}$ of iron sulphate and phosphorous each with 10 $\mathrm{lb} /$ yard $^{3} \quad 19 \mathrm{~N}-1.8 \mathrm{P}-5.8 \mathrm{~K}$ slowrelease Wilbro fertilizer (Harrell's, Norway, S.C.) incorporated into the media (Bork Nurseries, Onarga, Ill.). The media containers were each surface-seeded with a 1:1:1 (by volume) mixture of annual bluegrass, common groundsel, and shepherd's purse (Valley Seed Service, Fresno, Calif.) applied at a volume of $1 / 8$ teaspoon in each container immediately after the application of treatments. A random count of the weed seed applied 
found $\approx 328$ seeds of annual bluegrass, 568 seeds of common groundsel, and 1539 seeds of shepherd's purse in $1 / 8$ teaspoon. A moist paper towel test indicated germination rates of $100 \%, 80 \%$, and $30 \%$ for annual bluegrass, common groundsel, and shepherd's purse, respectively. Containers were hand-watered after application of weed seeds.

A total of 12 treatments, including a control treatment consisting of no herbicide and only water as a carrier, were included for each of two harvest dates, 45 and $120 \mathrm{~d}$ after treatment (DAT). Other treatments included spray applications of herbicides oryzalin (Surflan A.S.; Dow Agrosciences, Indianapolis, Ind.) at $2 \mathrm{lb} /$ acre a.i. and diuron (Diuron 80 DF; Makhteshim-Agan of North America, Raleigh, N.C.) at $1 \mathrm{lb} /$ acre a.i. with water as a carrier, an herbicide with one of the mulches as a carrier, or the mulches alone. Five replications were included for a total of 120 containers (experimental units). The herbicide-treated mulches were prepared by placing each mulch type in a 0.2 -inch-thick layer on a plastic sheet in a measured area of $38 \times 38$ inches. This area was determined by calculation to be sufficient to mulch 40 containers: 10 containers for the efficacy part and 30 for the phytotoxicity part of the experiment at a depth of 0.2 inch. The plastic sheet was laid out in an enclosed structure at LHRC. On 29 May, the mulches were sprayed with the herbicides using a carbon dioxide-pressurized backpack sprayer equipped with TeeJet 8002VS nozzles (Spraying Systems Co., TeeJet Midwest, Urbandale, Iowa) delivering $29.7 \mathrm{gal} /$ acre. Applications were made at $2 \mathrm{lb} /$ acre a.i. for oryzalin and at $1 \mathrm{lb} /$ acre a.i. for diuron. The herbicide-treated mulches were allowed to air-dry on the plastic sheet for 42 to 48 h before application to the containers. Herbicide treatments with a water carrier were applied to the containers following specifications used for the herbicidetreated mulches.

All treatments were applied on 31 May 2002. After application of treatments and the weed seeds, the containers were spaced at a distance of $12 \times 12$ inches center-to-center on a raised gravel bed in a completely randomized design. No supplemental fertilization was given during the experiment. A sulfuric acid injector was used to maintain the irrigation water $\mathrm{pH}$ between 5.2 and 6.2. All containers were hand-watered as needed throughout the experiment. Electrical conductivity (EC) and $\mathrm{pH}$ were measured biweekly in containers of the control treatment using a combination $\mathrm{pH}$ and EC meter (HI 98129; Hanna Instruments, Ann Arbor, Mich.) to ensure optimal growing conditions.

Visual ratings and shoot dry biomass were collected 45 DAT on 16 July and 120 DAT on 29 Sept. For the efficacy experiment, visual ratings of 1 to 10 were assigned, in which " 1 " corresponded to no weed control and "10" was complete control. A rating of " 7 " or above was considered to be commercially acceptable. After assigning the visual ratings, the weeds were harvested to determine the weed shoot biomass.

No weed seeds were sown in the phytotoxicity containers. Three species of 1-year-old woody ornamentals were planted on 15 May in 6.5-inchdiameter containers (nursery l-gal) using the same media and treatments as in the efficacy experiment. There were a total of 360 containers (experimental units). Container spacing, experimental design, application of irrigation water, and $\mathrm{pH}$ and $\mathrm{EC}$ readings were done as previously described. Visual evaluation of ornamental plants at 45 and 120 DAT was done on a scale of 1 to 10 , in which "l" represented a vigorous, healthy plant and "10" represented a dead plant. A rating of " 3 " or below was considered to be commercially acceptable. After the visual ratings, the shoots of each woody plant were harvested and dried to determine dry biomass.

In 2003, rice hulls were obtained from Home Nurseries, Albers, Ill., and pine bark from Western Organics, Tempe, Ariz. Leaf pellets manufactured in 2002 were used for 2003. 'Goldflame' spirea and 'Hetz Midget' american arborvitae (Bork Nurseries, Onarga, Ill.) were planted on 7 May using a potting machine (model no. 11103; Bouldin and Lawson, McMinnville, Tenn.). 'Snowmound' nippon spirea (Spring Meadow Nursery, Grandhaven, Mich.) were planted on 21 May. The herbicidetreated mulches were prepared on 27 May using the same procedures as in 2002. Treatment applications were made on 29 May. A moist paper towel test indicated germination rates of $100 \%, 70 \%$, and $30 \%$ for annual bluegrass, common groundsel, and shepherd's purse, respectively. Visual ratings and shoot dry biomass were determined for 45 and 120 DAT on 14 July and 22 Sept., respectively. Data collection and harvesting were conducted like in 2002. The visual scales in 2003, for both the efficacy and phytotoxicity experiments, were formulated with the aid of colored photographs of the visual rating scales in 2002. Data were analyzed with proc mixed in SAS (release 8.02; SAS Institute, Cary, N.C.). Tukey's Studentized range test $(P \leq 0.05)$ was used for mean separations. Letters for mean separation in proc mixed were assigned using the macro "PDMIX 800" (Saxton, 1998).

\section{Results}

EfficACY. There was a year-byherbicide interaction for the combined weed shoot biomass at 45 DAT in 2002 and 2003 (Table 1). The lowest weed biomass was observed in 2002 in oryzalin and diuron treatments. Containers with no herbicide treatment and those treated with oryzalin in 2003 gave the highest combined weed shoot biomass at 45 DAT. The combined weed shoot biomass was less in 2002 than in 2003 for all of the treatments at $45 \mathrm{DAT}$.

For visual ratings at $45 \mathrm{DAT}$, a year-by-herbicide-by-carrier interaction was found (Table 2). In 2002, containers treated with leaf pellet

Table 1. Effect of the year-byherbicide interaction on weed shoot dry biomass evaluated $45 \mathrm{~d}$ after treatment in 2002 and 2003.

\begin{tabular}{|c|c|c|}
\hline \multirow[b]{2}{*}{ Herbicide $^{\mathrm{x}}$} & \multicolumn{2}{|c|}{$\begin{array}{c}\text { Weed shoot } \\
\text { dry biomass }(g)^{z, y}\end{array}$} \\
\hline & 2002 & 2003 \\
\hline None & $8.3 b^{w}$ & $17.2 \mathrm{a}$ \\
\hline Ory & $0.8 \mathrm{c}$ & $14.0 \mathrm{a}$ \\
\hline Diuron & $0.4 \mathrm{c}$ & $10.5 \mathrm{~b}$ \\
\hline \multicolumn{3}{|c|}{$\begin{array}{l}{ }^{2} \mathrm{~g}=0.0353 \mathrm{oz} . \\
{ }^{y} \text { Total of all weed species present in each container, } \\
\text { including the hand-seeded and other weed species. } \\
{ }^{0} \text { Oryzalin and diuron applied at } 2 \text { and } \mathrm{l} \mathrm{lb} / \mathrm{acre} \\
\left(2.2 \text { and } 1.1 \mathrm{~kg} \cdot \mathrm{ha}^{-1}\right) \text { a.i., respectively. } \\
\text { "Means with the same letter across both columns are } \\
\text { not significantly different using Tukey's Studentized } \\
\text { range test }(P \leq 0.05) \text {. }\end{array}$} \\
\hline
\end{tabular}


Table 2. Effect of the year-by-herbicide-by-carrier interaction on efficacy visual ratings evaluated 45 and $120 \mathrm{~d}$ after treatment (DAT) in 2002 and 2003.

\begin{tabular}{|c|c|c|c|c|c|c|c|c|c|c|c|c|}
\hline \multirow[b]{4}{*}{ Carrier } & \multicolumn{12}{|c|}{ Efficacy visual ratings $(1-10 \text { scale })^{\mathrm{z}}$} \\
\hline & \multicolumn{6}{|c|}{$45 \mathrm{DAT}$} & \multicolumn{6}{|c|}{$120 \mathrm{DAT}$} \\
\hline & \multicolumn{2}{|c|}{ None } & \multicolumn{2}{|c|}{ Oryzalin } & \multicolumn{2}{|c|}{ Diuron $^{y}$} & \multicolumn{2}{|c|}{ None $^{y}$} & \multicolumn{2}{|c|}{ Oryzalin $^{\mathrm{y}}$} & \multicolumn{2}{|c|}{ Diuron $^{y}$} \\
\hline & 2002 & 2003 & 2002 & 2003 & 2002 & 2003 & 2002 & 2003 & 2002 & 2003 & 2002 & 2003 \\
\hline Water & $1.0 \mathrm{~d}^{\mathrm{x}}$ & $1.6 \mathrm{~d}$ & $8.0 \mathrm{ab}$ & $3.0 \mathrm{bcd}$ & $8.6 \mathrm{ab}$ & $5.0 \mathrm{a}$ & $1.6 \mathrm{c}$ & $1.6 \mathrm{~d}$ & $5.0 \mathrm{ab}$ & $5.8 \mathrm{ab}$ & $7.0 \mathrm{a}$ & $6.6 \mathrm{ab}$ \\
\hline Rice hulls & $2.0 \mathrm{~cd}$ & $1.6 \mathrm{~d}$ & $6.2 \mathrm{ab}$ & $4.0 \mathrm{abc}$ & $9.8 \mathrm{a}$ & $4.6 \mathrm{ab}$ & $1.6 \mathrm{c}$ & $2.0 \mathrm{~cd}$ & $5.2 \mathrm{ab}$ & $4.2 \mathrm{bc}$ & $6.8 \mathrm{a}$ & $5.6 \mathrm{ab}$ \\
\hline Leaf pellets & $5.0 \mathrm{bc}$ & $1.2 \mathrm{~d}$ & $6.6 \mathrm{ab}$ & $2.4 \mathrm{~cd}$ & $6.8 \mathrm{ab}$ & $4.4 \mathrm{ab}$ & $2.6 \mathrm{bc}$ & $1.4 \mathrm{~d}$ & $3.4 \mathrm{bc}$ & $4.8 \mathrm{ab}$ & $4.8 \mathrm{ab}$ & $5.0 \mathrm{ab}$ \\
\hline
\end{tabular}

${ }^{2}$ Efficacy visual ratings of 1 (no weed control) to 10 (complete weed control). A rating of 7 or above was considered commercially acceptable.

y Oryzalin and diuron applied at 2 and $1 \mathrm{lb} /$ acre $\left(2.2\right.$ and $\left.1.1 \mathrm{~kg} \cdot \mathrm{ha}^{-1}\right)$ a.i., respectively.

${ }^{x}$ Means with the same letter within a column are not significantly different using Tukey's Studentized range test $(P \leq 0.05)$.

mulch alone had higher efficacy ratings than water alone. Rice hulls and pine bark applied alone gave efficacy visual ratings equivalent to water alone. For 2003, the organic mulches alone gave equivalent ratings to water alone. In 2003, diuron with water and with the three mulches had the best visual ratings for weed control along with oryzalin with rice hulls at 45 DAT. In both years at $45 \mathrm{DAT}$, the herbicide-organic carrier combinations produced efficacy visual ratings equivalent to the use of water as a carrier for both herbicides. At 120 DAT in 2002 and 2003, only the main effect of herbicide was significant for the combined weed shoot dry biomass (Table 3 ). Containers treated with oryzalin and diuron had lower weed biomass than containers in which no herbicide was applied.

For the efficacy visual ratings 120 DAT, there was a year-by-herbicide-by-carrier interaction (Table 2 ). The presence of organic mulches alone was not sufficient to control weeds as indicated by visual ratings being equivalent to water alone in 2002 and 2003. In both years, all

Table 3. Main effect of herbicide on weed shoot dry biomass evaluated $120 \mathrm{~d}$ after treatment in 2002 and 2003.

\begin{tabular}{|c|c|}
\hline Herbicide $^{\mathrm{z}}$ & $\begin{array}{l}\text { Weed shoot dry } \\
\text { biomass }(g)^{\mathrm{y}, \mathrm{x}} \\
\end{array}$ \\
\hline None & 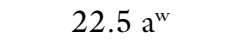 \\
\hline Oryzalin & $5.7 \mathrm{~b}$ \\
\hline Diuron & $3.6 \mathrm{~b}$ \\
\hline \multicolumn{2}{|c|}{ 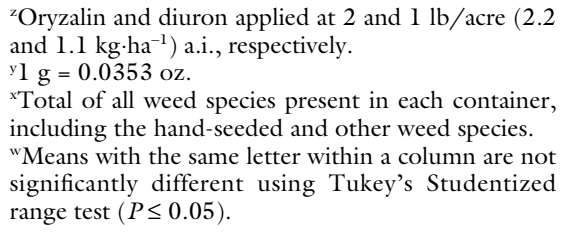 } \\
\hline
\end{tabular}

organic carriers produced efficacy visual ratings equivalent to the use of water as a carrier for both herbicides at 120 DAT. Oryzalin with pine bark had a higher visual rating than oryzalin with leaf pellets in 2002 . Among the applied weed species, common groundsel was the predominant weed species in oryzalin treatments at 45 DAT, whereas at 120 DAT, annual bluegrass was most prominent in diuron treatments. Although the applied weed species were the most prevalent, london rocket (Sisymbrium irio), annual sowthistle (Sonchus oleraceus), redroot pigweed (Amaranthus retroflexus), common lambsquarters (Chenopodium album), and canada thistle (Cirsium arvense) were also found in 2002 . London rocket was the most prominent of the nonseeded weeds in 2002. In 2003, london rocket, euphorbia (Chamaesyce sp.), yellow

Table 4. Effect of the year-by-species-by-carrier interaction on shoot dry biomass for three woody plant species evaluated $45 \mathrm{~d}$ after treatment in 2002 and 2003.

\begin{tabular}{llcr}
\hline & & \multicolumn{2}{c}{$\begin{array}{c}\text { Crop shoot dry } \\
\text { biomass }(\mathbf{g})^{\mathrm{z}}\end{array}$} \\
\cline { 2 - 4 } Species & Carrier & $\mathbf{2 0 0 2}$ & $\mathbf{2 0 0 3}$ \\
\hline Goldflame spirea & Water & $3.8 \mathrm{e}^{\mathrm{y}}$ & $15.9 \mathrm{c}$ \\
Goldflame spirea & Rice hulls & $4.4 \mathrm{e}$ & $19.5 \mathrm{abc}$ \\
Goldflame spirea & Leaf pellets & $3.8 \mathrm{e}$ & $16.7 \mathrm{bc}$ \\
Goldflame spirea & Pine bark & $5.0 \mathrm{e}$ & $21.7 \mathrm{a}$ \\
Hetz Midget american arborvitae & Water & $2.8 \mathrm{e}$ & $3.6 \mathrm{e}$ \\
Hetz Midget american arborvitae & Rice hulls & $4.3 \mathrm{e}$ & $4.8 \mathrm{e}$ \\
Hetz Midget american arborvitae & Leaf pellets & $4.3 \mathrm{e}$ & $4.1 \mathrm{e}$ \\
Hetz Midget american arborvitae & Pine bark & $5.8 \mathrm{e}$ & $3.5 \mathrm{e}$ \\
Snowmound nippon spirea & Water & $10.7 \mathrm{~d}$ & $16.4 \mathrm{bc}$ \\
Snowmound nippon spirea & Rice hulls & $10.4 \mathrm{~d}$ & $19.1 \mathrm{abc}$ \\
Snowmound nippon spirea & Leaf pellets & $9.7 \mathrm{~d}$ & $16.0 \mathrm{c}$ \\
Snowmound nippon spirea & Pine bark & $11.7 \mathrm{~d}$ & $19.8 \mathrm{ab}$ \\
\hline
\end{tabular}

\section{${ }^{\mathrm{z}} 1 \mathrm{~g}=0.0353 \mathrm{oz}$}

${ }^{\mathrm{y}}$ Means with the same letter across both columns are not significantly different using Tukey's Studentized range test $(P \leq 0.05)$. wood sorrel (Oxalisstricta), and horseweed (Conyza canadensis) were the most common nonseeded weed species. The presence of these other weed species indicates contamination of the supplied weed seed mixture or contamination from the surrounding area. The total biomass of the weeds was only affected in a minor way as a result of the presence of other weed species based on visual observations.

Рнyтотохісіту. There was a year-by-species-by-carrier interaction for the phytotoxicity crop shoot biomass at 45 DAT (Table 4). There were no differences in dry biomass among carrier treatments within any of the woody plant species at 45 DAT in 2002. 'Goldflame' spirea and 'Snowmound' nippon spirea in 2003 had greater biomass in pine barktreated containers than with leaf pellets, but spirea biomass in pine bark treatments were not different from 
those treated with rice hulls for both species. Pine bark treatment of 'Goldflame' spirea in 2003 gave higher biomass than with a water carrier. For 'Hetz Midget' american arborvitae, there were no significant differences in shoot dry biomass in either year. Plant growth for both spirea species was greater in 2003 than in 2002.

For the phytotoxicity visual ratings at 45 DAT in 2002, the yearby-species-by-herbicide-by-carrier interaction was significant (Table 5). Phytotoxicity was not apparent for either 'Goldflame' spirea or 'Snowmound' nippon spirea. For 'Hetz Midget' american arborvitae in 2002, diuron with water had the highest phytotoxicity and was the only treatment significantly different from the control treatment. The phytotoxicity mean for diuron with water was not different from oryzalin with water, rice hulls, or leaf pellets. However, diuron phytotoxicity on the 'Hetz Midget' american arborvitae was alleviated when diuron was applied with any of the organic carriers as compared with spray application of diuron with water. Visual means for 'Hetz Midget' american arborvitae treated with diuron on rice hulls, leaf pellets, and pine bark were 1.6 for all three treatments. Phytotoxicity was not observed in 2003 .

There was a year-by-species-bycarrier interaction for crop shoot dry biomass at 120 DAT (Table 6). All organic carriers produced equivalent or greater crop biomass than their respective water treatments for all ornamental species. For 'Goldflame' spirea in 2002, pine bark improved the crop biomass over the water carrier. In 2003, all organic carriers produced crop biomass equivalent to their respective water carriers. Crop shoot biomass for the two spirea species in 2003 was greater than in 2002. For the phytotoxicity visual rating $120 \mathrm{DAT}$, there was a fourway interaction of year by species by herbicide by carrier for crop plant phytotoxicity (Table 7). For 2002, diuron with water on 'Goldflame' spirea had the highest phytotoxicity rating. Diuron phytotoxicity, based on visual ratings, was alleviated in 'Goldflame' spirea when rice hulls and leaf pellets were used as carriers for diuron. Phytotoxicity ratings for all crop species were minimal in 2003.

Table 5. Effect of the year-by-species-by-herbicide-by-carrier interaction on phytotoxicity visual ratings evaluated $45 \mathrm{~d}$ after treatment for three woody plant species in 2002 and 2003.

\begin{tabular}{|c|c|c|c|c|c|c|c|}
\hline \multirow[b]{3}{*}{ Herbicide $^{\mathrm{y}}$} & \multirow[b]{3}{*}{ Carrier } & \multicolumn{6}{|c|}{ Phytotoxicity visual ratings $(1-10 \text { scale })^{\mathrm{z}}$} \\
\hline & & \multicolumn{2}{|c|}{$\begin{array}{c}\text { Goldflame } \\
\text { spirea }\end{array}$} & \multicolumn{2}{|c|}{$\begin{array}{c}\text { Hetz Midget } \\
\text { american } \\
\text { arborvitae }\end{array}$} & \multicolumn{2}{|c|}{$\begin{array}{l}\text { Snowmound } \\
\text { nippon spirea }\end{array}$} \\
\hline & & 2002 & 2003 & 2002 & 2003 & 2002 & 2003 \\
\hline None & ater & $2 b^{x}$ & $2.0 \mathrm{abc}$ & $2.6 \mathrm{~b}$ & $2.4 \mathrm{abc}$ & $1.6 \mathrm{~b}$ & $1.6 \mathrm{bc}$ \\
\hline None & Rice hulls & $.0 \mathrm{~b}$ & $2.2 \mathrm{abc}$ & $2.5 \mathrm{~b}$ & $2.0 \mathrm{abc}$ & $1.8 \mathrm{~b}$ & $1.6 \mathrm{bc}$ \\
\hline None & Leaf pellet & $4.2 \mathrm{ab}$ & $1.8 \mathrm{abc}$ & $2.6 \mathrm{~b}$ & $3.0 \mathrm{abc}$ & $4.4 \mathrm{ab}$ & $1.8 \mathrm{abc}$ \\
\hline None & Pine bark & $1.8 \mathrm{~b}$ & $1.4 \mathrm{bc}$ & $3.2 \mathrm{~b}$ & $2.8 \mathrm{abc}$ & $2.0 \mathrm{~b}$ & $1.4 \mathrm{bc}$ \\
\hline Oryzalin & Water & $4.8 \mathrm{ab}$ & $3.8 \mathrm{ab}$ & $4.3 \mathrm{ab}$ & $2.2 \mathrm{abc}$ & $1.8 \mathrm{~b}$ & $3.0 \mathrm{abc}$ \\
\hline Oryzalin & Rice hulls & $4.2 \mathrm{ab}$ & $2.2 \mathrm{abc}$ & $4.2 \mathrm{ab}$ & $2.0 \mathrm{abc}$ & $2.4 \mathrm{~b}$ & $1.4 \mathrm{bc}$ \\
\hline Oryzalin & Leaf pellets & $4.4 \mathrm{ab}$ & $2.2 \mathrm{abc}$ & $5.4 \mathrm{ab}$ & $2.0 \mathrm{abc}$ & $1.6 \mathrm{~b}$ & $2.0 \mathrm{abc}$ \\
\hline Oryzalin & Pine bark & $4.6 \mathrm{ab}$ & $1.2 \mathrm{c}$ & $1.0 \mathrm{~b}$ & $2.8 \mathrm{abc}$ & $2.0 \mathrm{~b}$ & $1.8 \mathrm{abc}$ \\
\hline Diuron & Water & $5.6 \mathrm{ab}$ & $4.2 \mathrm{a}$ & $9.2 \mathrm{a}$ & $3.6 \mathrm{abc}$ & $2.8 \mathrm{~b}$ & $2.0 \mathrm{abc}$ \\
\hline Diuron & Rice hulls & $4.4 \mathrm{ab}$ & $3.0 \mathrm{abc}$ & $1.6 \mathrm{~b}$ & $2.0 \mathrm{abc}$ & $2.8 \mathrm{~b}$ & $1.8 \mathrm{abc}$ \\
\hline Diuron & Leaf pellets & $3.8 \mathrm{~b}$ & $1.8 \mathrm{abc}$ & $1.6 \mathrm{~b}$ & $2.0 \mathrm{abc}$ & $4.0 \mathrm{~b}$ & $1.8 \mathrm{abc}$ \\
\hline Diuron & Pine bark & $2.4 \mathrm{~b}$ & $1.8 \mathrm{abc}$ & $1.6 \mathrm{~b}$ & $3.2 \mathrm{abc}$ & $1.8 \mathrm{~b}$ & $1.4 \mathrm{bc}$ \\
\hline
\end{tabular}

${ }^{2}$ Phytotoxicity visual ratings of 1 (no phytotoxicity) to 10 (dead plant). A rating of 3 or below was considered commercially acceptable.

${ }^{y^{\prime}}$ Oryzalin and diuron applied at 2 and $1 \mathrm{lb} /$ acre $\left(2.2\right.$ and $\left.1.1 \mathrm{~kg} \cdot \mathrm{ha}^{-1}\right)$ a.i., respectively.

${ }^{x}$ Means with the same letter within a column are not significantly different using Tukey's Studentized range test $(P \leq 0.05)$.

Table 6. Effect of the year-by-species-by-carrier interaction on shoot dry biomass for three woody plant species $120 \mathrm{~d}$ after treatment in 2002 and 2003.

\begin{tabular}{llcc}
\hline & & \multicolumn{2}{c}{ Crop shoot dry biomass $(\mathbf{g})^{\mathbf{z}}$} \\
\cline { 3 - 4 } Species & Carrier & $\mathbf{2 0 0 2}$ & $\mathbf{2 0 0 3}$ \\
\hline Goldflame spirea & Water & $10.0 \mathrm{ijk}$ & $39.1 \mathrm{bcd}$ \\
Goldflame spirea & Rice hulls & $15.7 \mathrm{hij}$ & $42.3 \mathrm{ab}$ \\
Goldflame spirea & Leaf pellets & $16.9 \mathrm{hi}$ & $37.3 \mathrm{bcde}$ \\
Goldflame spirea & Pine bark & $21.3 \mathrm{gh}$ & $39.7 \mathrm{bc}$ \\
Hetz Midget american arborvitae & Water & $6.8 \mathrm{k}$ & $11.0 \mathrm{ijk}$ \\
Hetz Midget american arborvitae & Rice hulls & $8.1 \mathrm{jk}$ & $11.0 \mathrm{ijk}$ \\
Hetz Midget american arborvitae & Leaf pellets & $9.9 \mathrm{ijk}$ & $12.7 \mathrm{ijk}$ \\
Hetz Midget american arborvitae & Pine bark & $9.5 \mathrm{jjk}$ & $10.5 \mathrm{ijk}$ \\
Snowmound nippon spirea & Water & $32.6 \mathrm{cdef}$ & $42.6 \mathrm{ab}$ \\
Snowmound nippon spirea & Rice hulls & $30.9 \mathrm{def}$ & $49.1 \mathrm{a}$ \\
Snowmound nippon spirea & Leaf pellets & $26.5 \mathrm{fg}$ & $39.1 \mathrm{bcd}$ \\
Snowmound nippon spirea & Pine bark & $30.1 \mathrm{ef}$ & $44.9 \mathrm{ab}$ \\
\hline
\end{tabular}

${ }^{\mathrm{z}} 1 \mathrm{~g}=0.0353 \mathrm{oz}$

${ }^{y}$ Means with the same letter across both columns are not significantly different using Tukey's Studentized range test $(P \leq 0.05)$.

\section{Discussion}

This research demonstrated that rice hulls, landscape leaf-waste pellets, and pine bark can serve as carriers for diuron and oryzalin to control weeds in container production of woody ornamentals. The use of these organic herbicide carriers can produce equivalent or, in a few cases, improved crop growth and effective weed control compared with use of water as a carrier. Based on the weed biomass data, long-term weed control (i.e., 120 DAT) can be obtained in containers treated with either oryzalin or diuron. Diuron with all three organic mulches or water gave good longterm weed control in both years (Table 2). Water, rice hulls, and pine bark were the best carriers for oryzalin in 2002 and in 2003, oryzalin with water, leaf pellets, and pine bark were the better performing treatments (Table 2). From personal observations and recordings of the relative abundance of the various weed species present in each container (data not shown), it was evident that the reason for lower efficacy ratings in 2003 as compared with 2002 was a 
Table 7. Effect of the year-by-species-by-herbicide-by-carrier interaction on phytotoxicity visual ratings $120 \mathrm{~d}$ after treatment for three woody plant species in 2002 and 2003.

\begin{tabular}{|c|c|c|c|c|c|c|c|}
\hline \multirow[b]{3}{*}{$\underline{\text { Herbicide }^{y}}$} & \multirow[b]{3}{*}{ Carrier } & \multicolumn{6}{|c|}{ Phytotoxicity visual ratings $(1-10 \text { scale })^{\mathrm{z}}$} \\
\hline & & \multicolumn{2}{|c|}{$\begin{array}{c}\text { Goldflame } \\
\text { spirea }\end{array}$} & \multicolumn{2}{|c|}{$\begin{array}{l}\text { Hetz Midget } \\
\text { american } \\
\text { arborvitae }\end{array}$} & \multicolumn{2}{|c|}{$\begin{array}{l}\text { Snowmound } \\
\text { nippon spirea }\end{array}$} \\
\hline & & 2002 & 2003 & 2002 & 2003 & 2002 & 2003 \\
\hline None & Water & $3.0 \mathrm{c}^{\mathrm{x}}$ & $1.6 \mathrm{ab}$ & $5.4 \mathrm{abc}$ & $2.6 \mathrm{ab}$ & $2.4 \mathrm{c}$ & $1.0 \mathrm{~b}$ \\
\hline None & Rice hulls & $3.8 \mathrm{abc}$ & $1.4 \mathrm{ab}$ & $4.4 \mathrm{abc}$ & $2.2 \mathrm{ab}$ & $3.0 \mathrm{c}$ & $1.8 \mathrm{ab}$ \\
\hline None & Leaf pellets & $2.4 \mathrm{c}$ & $2.0 \mathrm{ab}$ & $3.2 \mathrm{bc}$ & $2.4 \mathrm{ab}$ & $4.0 \mathrm{abc}$ & $1.6 \mathrm{ab}$ \\
\hline None & Pine bark & $2.8 \mathrm{c}$ & $1.6 \mathrm{ab}$ & $2.8 \mathrm{c}$ & $2.6 \mathrm{ab}$ & $2.4 \mathrm{c}$ & $1.6 \mathrm{ab}$ \\
\hline Oryzalin & Water & $5.8 \mathrm{abc}$ & $3.2 \mathrm{a}$ & $3.0 \mathrm{c}$ & $2.6 \mathrm{ab}$ & $4.0 \mathrm{abc}$ & $2.8 \mathrm{ab}$ \\
\hline Oryzalin & Rice hulls & $3.2 \mathrm{bc}$ & $1.8 \mathrm{ab}$ & $4.0 \mathrm{abc}$ & $2.0 \mathrm{ab}$ & $3.2 \mathrm{bc}$ & $1.2 \mathrm{~b}$ \\
\hline Oryzalin & Leaf pellets & $3.0 \mathrm{c}$ & $2.2 \mathrm{ab}$ & $5.4 \mathrm{abc}$ & $1.8 \mathrm{ab}$ & $3.0 \mathrm{c}$ & $2.0 \mathrm{ab}$ \\
\hline Oryzalin & Pine bark & $4.2 \mathrm{abc}$ & $2.8 \mathrm{ab}$ & $4.2 \mathrm{abc}$ & $1.8 \mathrm{ab}$ & $3.2 \mathrm{bc}$ & $1.6 \mathrm{ab}$ \\
\hline Diuron & Water & $7.6 \mathrm{a}$ & $2.6 \mathrm{ab}$ & $7.5 \mathrm{ab}$ & $2.0 \mathrm{ab}$ & $3.2 \mathrm{bc}$ & $1.8 \mathrm{ab}$ \\
\hline Diuron & Rice hulls & $3.2 \mathrm{bc}$ & $2.8 \mathrm{ab}$ & $3.4 \mathrm{abc}$ & $1.8 \mathrm{ab}$ & $3.4 \mathrm{abc}$ & $1.4 \mathrm{ab}$ \\
\hline Diuron & Leaf pellets & $2.6 \mathrm{c}$ & $2.8 \mathrm{ab}$ & $3.6 \mathrm{abc}$ & $1.4 \mathrm{ab}$ & $4.2 \mathrm{abc}$ & $1.8 \mathrm{ab}$ \\
\hline Diuron & Pine bark & $4.2 \mathrm{abc}$ & $2.2 \mathrm{ab}$ & $3.2 \mathrm{bc}$ & $2.2 \mathrm{ab}$ & $4.2 \mathrm{abc}$ & $1.2 \mathrm{~b}$ \\
\hline
\end{tabular}

${ }^{2}$ Phytotoxicity visual ratings of 1 (no phytotoxicity) to 10 (dead plant). A rating of 3 or below was considered commercially acceptable.

'Oryzalin and diuron applied at 2 and $1 \mathrm{lb} / \mathrm{acre}\left(2.2\right.$ and $\left.1.1 \mathrm{~kg} \cdot \mathrm{ha}^{-1}\right)$ a.i., respectively.

'Means with the same letter within a column are not significantly different using Tukey's Studentized range test $(P \leq 0.05)$.

high common groundsel biomass. It seems that the growing season in 2003 favored common groundsel germination and growth. In fact, 2003 was a year that favored not only high weed biomass and growth, but in general, growth of all plants. This is also evidenced by the generally lower phytotoxicity visual ratings at 120 DAT and increased shoot dry biomass of 'Goldflame' and 'Snowmound' nippon spirea at 120 DAT in 2003.

In either year, minimal or no phytotoxicity was observed for both spirea species treated with oryzalin and diuron treatments, except for plants treated with diuron and water. Our observations for oryzalin treatments were similar to a study conducted in 1979 and 1980 on seven container-grown woody ornamentals (Creager, 1982). That study showed that oryzalin applied at $2.2 \mathrm{~kg} \cdot \mathrm{ha}^{-1}$ gave commercially acceptable weed control for $\approx 2$ months with minimal or no injury to the crop plants. However, in another study, containergrown perennial phlox (Phlox paniculata) were injured $88 \%$ and $93 \%$ from oryzalin applications of 2.3 and 4.6 $\mathrm{kg} \cdot \mathrm{ha}^{-1}$ a.i., respectively (Staats and Klett, 1993).

In some treatments, the organic carriers increased the shoot biomass of the spirea. In 2002, pine bark increased 'Goldflame' spirea biomass at 120 DAT, whereas in 2003, pine bark increased 'Goldflame' spirea biomass at 45 DAT. In the case of 'Hetz Midget' american arborvitae, plants appeared stressed in 2002 and the stress was reflected in the visual phytotoxicity ratings at $45 \mathrm{DAT}$. For 'Hetz Midget' american arborvitae in 2002, diuron with water produced the highest phytotoxicity rating and was the only treatment different from the control treatment. However, diuron phytotoxicity on the 'Hetz Midget' american arborvitae was alleviated when diuron was applied with any of the organic mulches. The visual phytotoxicity was, however, not evident in the biomass data at 45 and 120 DAT. This is likely the result of the slow-growing nature of the cultivar, not growing more than a few inches annually (Flint, 1983) and not exceeding 3 to $4 \mathrm{ft}$ in height (Dirr, 1990). The phytotoxic symptoms on the 'Hetz Midget' american arborvitae varied from leaf scorch and necrosis to death of the plant shoot. These observed symptoms were somewhat consistent with a study in which 'Pink Icicle' camellia (Camellia japonica), 'Anthony Waterer' spirea (Spiraea $\times$ bumalda), and 'Big Blue' liriope (Liriope muscari) were treated with diuron applied postemergent at $0.14,0.28,0.56$, and $1.12 \mathrm{~kg} \cdot \mathrm{ha}^{-1}$ a.i. (Simpson et al., 2004). The initial injury from diuron on all three species was characterized by marginal chlorosis with the injury increasing linearly with increasing application rates in camellia and spirea. However, by $60 \mathrm{DAT}$, the three species fully recovered from the injury. Stress resulting from phytotoxicity may account for the lack of diuron registration for ornamental crops in Illinois, although it is registered for such use in a few states (Crop Data Management Systems, 2006). The stress could also be partly attributed to the high temperatures of 2002 at Urbana, especially at the time of treatment application and in the following few weeks. The mean temperature of $80.6^{\circ} \mathrm{F}$ tied the record warm temperature for 31 May, the date of treatment application (Illinois State Water Survey, 2002a). The monthly mean average temperature for June in 2002 was $73.9^{\circ} \mathrm{F}$ versus $67.8^{\circ} \mathrm{F}$ in 2003 (Illinois State Water Survey, 2002b). High temperatures are known to increase the diffusion rate of herbicides through the cuticle and cell membrane of plants and, as a result, herbicide injury symptoms on plants under warm conditions are not unusual (Wanamarta and Penner, 1989). The extreme weather of 2002 may have provided an ideal testing environment for evaluation of phytotoxicity. Injury from oryzalin treatments on 'Hetz Midget' american arborvitae were minimal or unobserved, consistent with a study in which 'Elegantissima' american arborvitae and 'Woodwardi' american arborvitae were treated with oryzalin at $1.1,2.2,4.4$, and $8.8 \mathrm{~kg} \cdot \mathrm{ha}^{-1}$ a.i., respectively, and no injury was observed (Kuhns and Haramaki, 1980).

This research demonstrates that organic mulches show potential to reduce the phytotoxic effects of an herbicide that is considered likely to cause some phytotoxicity to woody ornamentals. The reduction in phytotoxicity while still maintaining weed control, found in this study, indicates that pine bark, rice hulls, and leaf-waste pellets can serve as slow-release herbicide carriers. This slow release could also minimize herbicide leaching problems. Recent studies have indicated that when organic mulches were used as carriers for preemergence herbicides, herbicide leaching was reduced 35\% to $74 \%$ as compared with direct spray 
applications of preemergence herbicides (Knight et al., 2001). Organic mulch treatments such as pine bark also increased biomass for both spirea. Thus, application of herbicides with organic mulches may reduce plant phytotoxicity and increase biomass of the woody ornamentals. At locations where the availability and choice of herbicides registered for use on ornamentals is limited, using organic mulches may be an alternative and relatively safer way of herbicide application to nursery containers as reflected from the diuron treatments. Future work could involve evaluating the mulches as carriers in other commonly used herbicide families in nursery settings and evaluating the mulches as herbicide carriers for other container-grown woody ornamentals.

\section{Literature cited}

Aaron, J.R. 1972. Pulverized pine bark. J. Royal Hort. Soc. 97:214-217.

Adams, D. 1990. Chemical weed control in containerized hardy ornamental nursery stock. Professional Hort. 4:70-75.

Appleton, B.L. and J.F. Derr. 1990. Use of geotextile disks for container weed control. HortScience 25:666-668.

Chong, C. 2003. Experiences with weed discs and other nonchemical alternatives for container weed control. HortTechnology 13:23-27.

Creager, R.A. 1982. Comparison of oxyfluorfen and oryzalin in container-grown woody ornamentals. HortScience 17:207-209.

Crop Data Management Systems, Inc. 2006. Product: Diuron 80DF. 10 Dec. 2006. <http://www.manainc.com/ Labels.htm>.

Dirr, M.A. 1990. Manual of woody landscape plants: Their identification, ornamental characteristics, culture, propagation and uses. Stipes, Champaign, Ill.

Einert, A.E. and E.C. Baker. 1973. Rice hulls as a growing medium component for cut tulips. J. Amer. Soc. Hort. Sci 98:556-558.

Flint, H.L. 1983. Landscape plants for eastern North America. Wiley, New York.

Fretz, T.A. 1972. Weed competition in container grown japanese holly. HortScience 7:485-486.

Gilliam, C.H., D.C. Fare, and A. Beasley. 1992. Nontarget herbicide losses from application of granular Ronstar to container nurseries. J. Environ. Hort. 10:175-176.

Gorski, S.F. 1993. Slow-release delivery system for herbicides in container-grown stock. Weed Technol. 7:894-899.

Holm, L., J. Doll, E. Holm, J. Panchho, and J. Herberger. 1997. World weeds: Natural histories and distribution. Wiley, New York.

Hough, J.H. and H.T. Barr. 1956. Possible uses for waste rice hulls in building materials and other products. Louisiana Agr. Expt. Sta. Bul. 507:1-36.

Illinois State Water Survey. 2002a. Local climatological data, Champaign-Urbana, Ill.-118740, May 2002. 10 Dec. 2006. <http://www.sws.uiuc.edu/atmos / statecli/Champ-Urb/may2002.pdf>.

Illinois State Water Survey. 2002b. Local climatological data, Champaign-Urbana, Ill.-118740, June 2002. 10 Dec. 2006. <http://www.sws.uiuc.edu/atmos/ statecli/Champ-Urb/jun2002.pdf>

Knight, P.R., C.H. Gilliam, S.L. File, and D. Reynolds. 2001. Mulches reduce herbicide loss in the landscape. Proc. Southern Nursery Assn. Res. Conf. 46:461-463.

Koncal, S.F., S.F. Gorske, and T.A. Fretz 1981. Slow-release herbicide formulation for weed control in container-grown plants. HortScience 16:83-84.

Kuhns, L.J. and C. Haramaki. 1980. An evaluation of 5 herbicides applied over liners representing 8 genera of ornamental plants. Proc. Northeastern Weed Sci. Soc. 34:340-346.

Laiche, A.J. 1990. Blends of pine bark with other growth media components for containerized azaleas. Res. Rpt. Mississippi Agr. For. Expt. Sta. 15:1-3.
Laiche, A.J. and V.E. Nash. 1990. Evaluation of composted rice hulls and a lightweight clay aggregate as components of container-plant growth media. J. Environ. Hort. 8:14-18.

Mathers, H.M. 2002. Get tough on weeds. Landscape Mgt. 41:72-79.

Mathers, H.M. 2003. Novel methods of weed control in containers. HortTechnology 3:28-34.

Monaco, T.J., C.S. Weller, and F.M. Ashton. 2002. Weed science: Principles and practices. 4th ed. Wiley, New York.

Pokorny, F.A. 1966. Pine bark as an organic amendment in production of container plants. Georgia Agr. Res. 7:8-9.

Popay, A.I. and E.H. Roberts. 1970. Ecology of Capsella bursa-pastoris (L.) Medik and Senecio vulgaris L. J. Ecol. 58:123-139.

Ren, Z. and J. Abbott. 1991. Seed dormancy in Mediterranean Sencecio vulgaris L. New Phytol. 117:673-678.

Saxton, A.M. 1998. A macro for converting mean separation output to letter groupings in Proc Mixed, p. 12431246. Proc. 23rd SAS Users Group Intl., SAS Institute Inc., Cary, N.C.

Simpson, C.V., C.H. Gilliam, J.E. Altland, G.R. Wehtje, and J.L. Sibley. 2004. Diuron: Postemergence oxalis control in container-grown plants. J. Environ. Hort. $22: 45-49$.

Staats, D. and J.E. Klett. 1993. Evaluation of weed control and phytotoxicity of preemergence herbicides applied to container-grown herbaceous and woody plants. J. Environ. Hort. 11:78-80.

Struve, D.K. and E.L. McCoy. 1996. Physical and chemical properties of media suitable for containerized bare root whip production. J. Environ. Hort. 14:137141.

Uva, R.H., J.C. Neal, and M.J. DiTomaso. 1997. Weeds of the Northeast. Comstock, New York.

Wanamarta, G. and D. Penner. 1989 Foliar absorption of herbicides. Rev. Weed Sci. 4:215-231. 